\title{
Reading the Isotopic Clochs.
}

- our research in age determination and stable isotopes requires reliable data and custom service. Teledyne Brown Engineering Environmental Services has the expertise and experience to meet these 1955 and are the only commercial laboratory that offers all major age determination techniques. requirements.

We have been pioneers in the industry since

We can assure you of reliable data because of well-staffed and well-equipped labs, intercalibration with major universities and government facilities, and through use of N.B.S. and international standards.

For the most reliable reading of the isotopic clocks, come to the experts.

\section{T TELEDYNE BROWN ENGINEERING} Environmental Services

50 Van Buren Avenue

Westwood, NJ 07675

201-664-7070

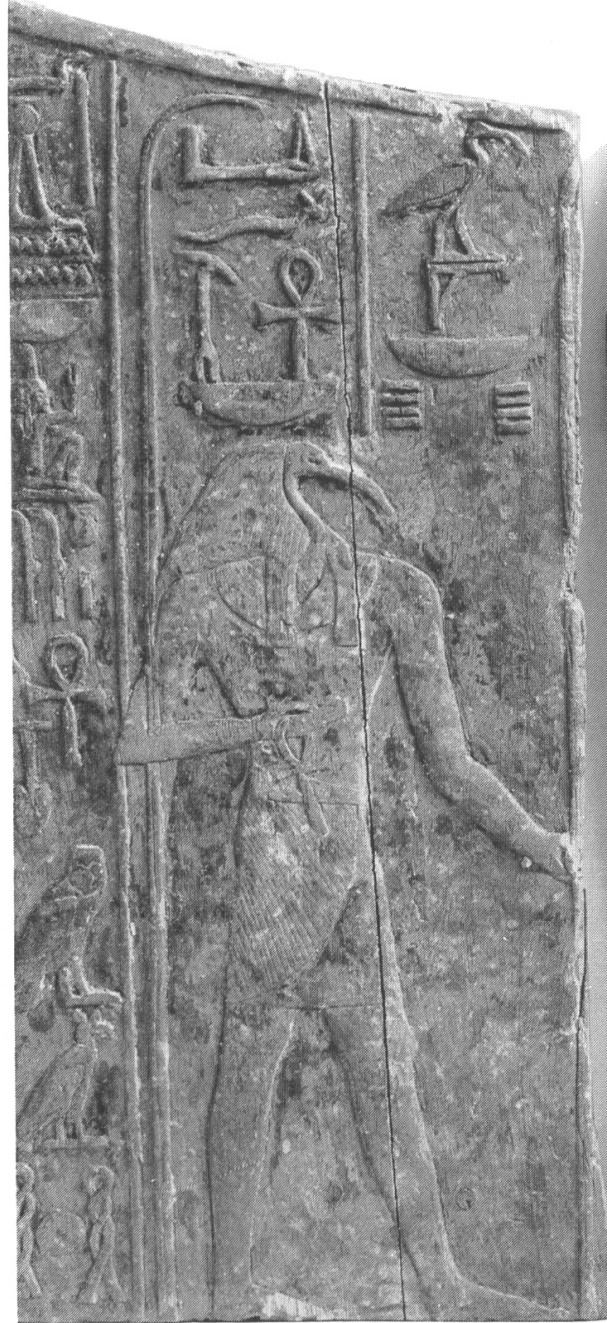

FAX: 201-664-5586

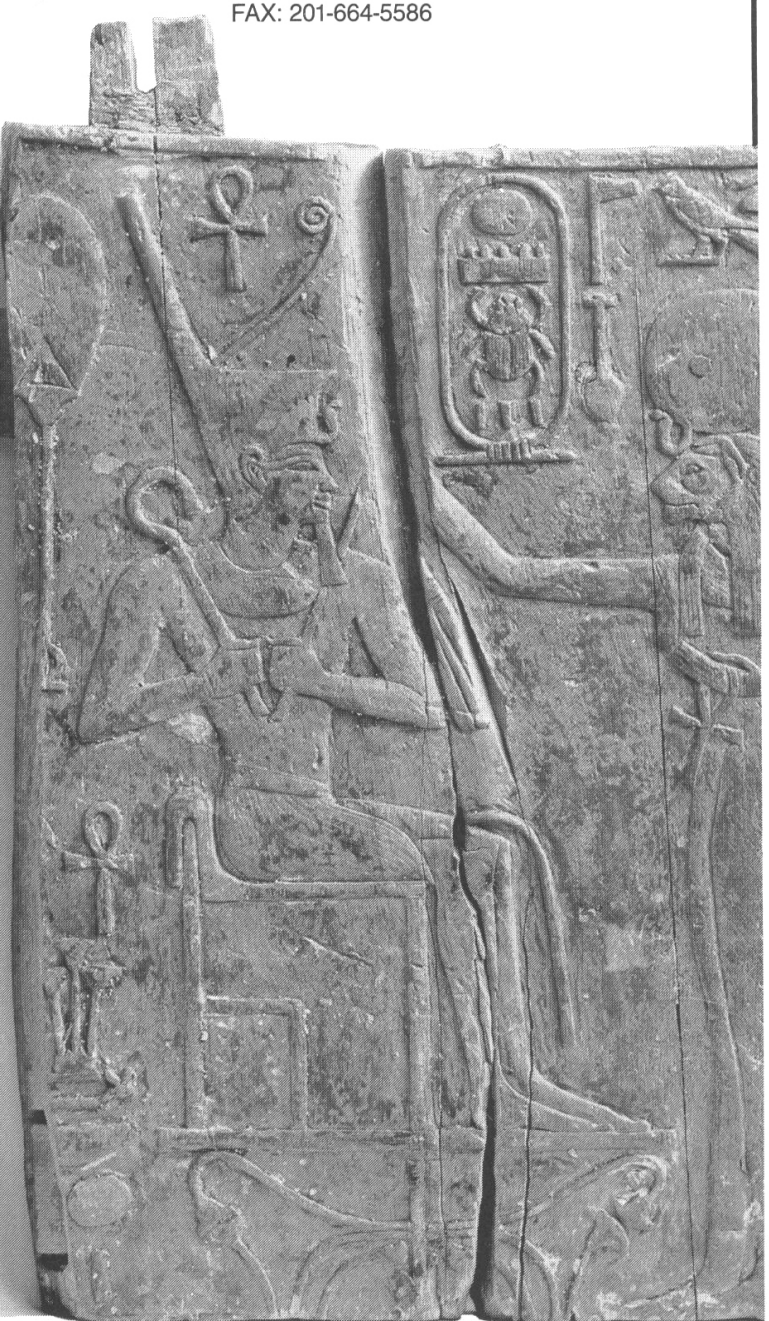




\section{Important new books from leading scholars}

\section{FLINTKNAPPING}

Making and Understanding Stone Tools

\section{By John C. Whittaker}

"Very attractive to readers interested in ancient crafts, survival skills, or the history of technology. . . f far superior to anything currently available."

$$
\text { -JAMES C. WoODS }
$$

$12 \mathrm{~b} \& \mathrm{w}$ photographs, 226 line drawings ISBN 79082-1, \$49.50 hardcover ISBN 79083-X, \$24.95 paperback

\section{SHIPS AND SEAFARING IN ANCIENT TIMES}

\section{By Lionel Casson}

The world's foremost authority on seamanship traces the development of the boat, from the most primitive crafts to the most powerful Greek warships, Roman merchant vessels, and slender galleys of the Vikings.

14 color and $116 \mathrm{~b} \&$ w illustrations ISBN 71162-X, \$24.95 paperback

\section{ANCIENT ARCHITECTURE OF THE SOUTHWEST}

\section{By William N. Morgan}

This comprehensive survey traces the ancient architectural evolution of the Southwest from humble pithouses to sophisticated, multi-story pueblos. Professionally rendered site drawings complete this richly diverse exploration.

$81 / 2 \times 11$ inches, 320 pages, 15 b\&w photographs,

171 line drawings

ISBN 75159-1, \$55.00 hardcover
ARCHAEOLOGY, VOLCAIISM, ANO REMOTE SENSING IN THE ARENAL REGIOH, COSTA RICA

Edited by Payson D. Sheets and Brian R. McKee

Using the latest remote sensing technology, the authors survey this volatile region where prehistoric societies contended with frequent natural disasters and prospered in a precarious environment. (August)

$81 / 2 \times 11,384$ pages, 83 b\&w photographs, 57 line drawings, 37 maps, 34 tables ISBN 77667-5, \$45.00 hardcover

\section{THE JUMANOS}

\section{Hunters and Traders of the South Plains}

\section{By Nancy Parrott Hickerson}

Hickerson proposes that history has misused the term "Jumano" as a generic name for a number of North American tribes. Hickerson argues that the Jumanos were a distinctive tribe which played a crucial role among Spanish colonies.

ISBN 73083-7, \$40.00 hardcover ISBN 73084-5, \$17.95 paperback

\section{AMERICA'S FIRST CUISINES}

\section{By Sophie D. Coe}

In easily digested prose, this pioneering work offers the first detailed description of the eating habits of the Aztecs, the Maya, and the Inca, including domestication, preparation, serving rituals, and preservation techniques.

ISBN 71155-7, $\$ 35.00$ hardcover

ISBN $71159-X, \$ 14.95$ paperback

Ask for our free anthropology catalog.

\section{UNIVERSITY OF TEXAS PRESS}

Box 7819 - Austin 78713 - ISBN prefix: 0-292 • To order, call 800-252-3206. 


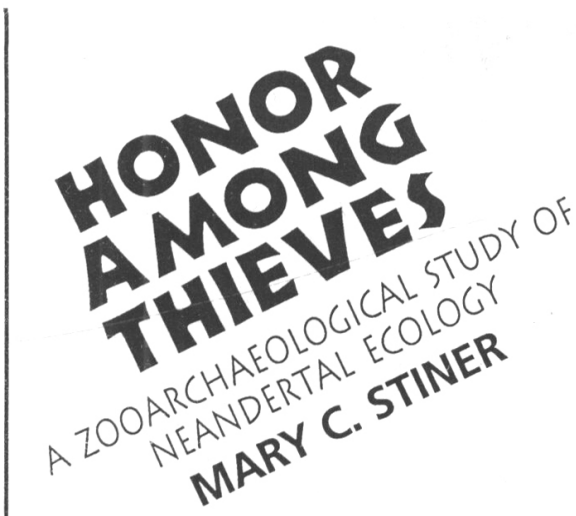

1 ary Stiner uses ecological niche theory to analyze and interpret several Middle Paleolithic archaeological and paleontological sites in southern Europe. Her concern is with how the hunting, scavenging and foraging behavior of Neandertals compared and contrasted with the subsistence behavior of other large predators living in the region at the time-lions, hyenas, and wolves, for example-and with how Neandertal subsistence behavior related to the behavior of the anatomically modern humans who subsequently came to dominate the area in the Upper Paleolithic.

"Most of the contents of this book are new: new theoretical approaches, new methods of analysis, new analytical comparisons and a range of new behavioral interpretations. [Mary Stiner's] analytical approach is clear and rigorous, and 'scientific' in the best sense of the word." -Paul A. Mellars, University of Cambridge

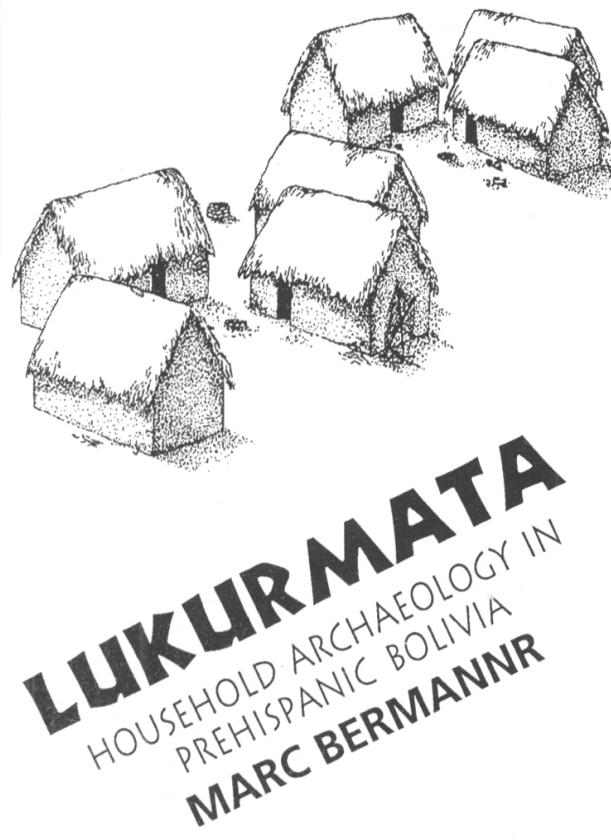

"An important book."

-Robert Whallon, University of Michigan

43 halftones. 107 line illustrations.

Cloth: \$69.50 ISBN 0-691-03456-7

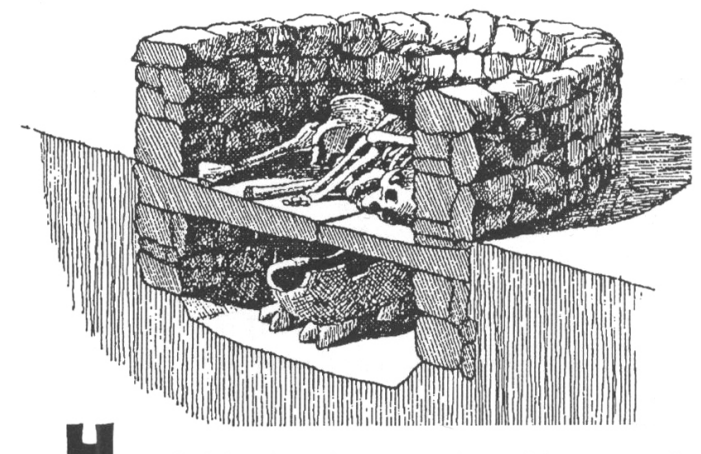

and regional settlement information, forms the basis for a unique local perspective of Andean prehistory in this study of the evolution of the site of Lukurmata, a preColumbian community in highland Bolivia. Presenting a "view from below" of Andean prehistory based on a remarkably extensive data set, Lukurmata is a rare case study of how prehispanic polities can be understood in new ways if prehistorians integrate the different lines of evidence available to them.

"This book offers one of the finest presentations of data from a deep archaeological sounding from any site in the Titicaca Basin. The interpretative framework is novel and important. The data are excellent."

-Charles Stanish, Field Museum of Natural History, Chicago

"Bermann does an admirable job in presenting new information and generating fresh ways to look at the archaeological record."

-Michael Moseley, University of Florida

100 line illustrations. 34 haltones.

Cloth: \$59.50 ISBN 0-691-03359-5

\section{PRINCETON UNIVERSITY PRESS}

AVAILABLE AT FINE BOOKSTORES OR DIRECTLY FROM THE PUBLISHER: 609-883-1759 


\section{ARCHAEOLOGY FROM CAMBRIDGE}

\section{Olduvai Gorge}

Vol. 5: Excavations in Beds III, IV and the Masek Beds

\section{Mary Leakey, Editor}

With Derk Roe

This book records the archaeological finds in the upper part of the Olduvai Gorge sequence, covering the period 1.2 to 0.4 million years ago, and includes artifacts and faunal remains excavated from sites in Beds III, IV and the Masek Beds. Contributors: R. L. Hay, Mary Leakey, D. A. Roe, $P$. Callow, P. R. Jones, Celia K. Nyamweru 33403-9 Hardback about $\$ 150.00$

\section{Territory, Time and State}

The Archaeological Development of the Gubbio Basin

\section{Simon Stoddart and}

\section{Caroline Malone, Editors}

Territory, Time and State explores the relationship between the physical and man-made environments of the Gubbio basin, taking issues related to Early Man, prehistoric settlement, the emergence of the citystate and its almost simultaneous domination by Rome. Contributors: Francesco Allegrucci, Catherine Backway, Edoardo Biondi, Gillian Clark, Mauro Coltorti, Peter Finke, Racbel Fulton, Jenny Harding, Rupert Housley, Christopher Hunt, Caroline Malone, Dorica Manconi, James McVicar, Timotby Reynolds, Mirjam Schomaker, Rene Sewuster, Jan Sevink, Simon Stoddart, Erik Van Waveren, Nicholas Whitebead, James Whitley, John Wilkins 35568-0 Hardback about $\$ 100.00$

\section{Factional Competition and Political Development in the New World \\ Elizabeth M. Brumfiel and \\ John W. Fox, Editors}

The case studies examine how factional competition in the kinship and political structures in ancient New World societies led to the development of chiefdoms, states and empires Contributors: Elizabetb M. Brumfiel, John E. Clark, Micbael Blake, Charles S. Spencer, Elsa M. Redmond Mary W. Helms, David G. Anderson, Helen Perlstein Pollard, Rudolf van Zantwijk, Frederic Hicks, Bruce E. Byland, Jobn M. D. Pohl, Stephen A. Kowalewski, Mary E. D. Pohl, Jobn W. Fox, Terence N. D'Altroy, Glenn Perusek

New Directions in Archaeology

38400-1 Hardback \$49.95

\section{Corpus Speculorum}

\section{Etruscorum}

\section{Richard Nicholls}

The first British fascicule to appear, this volume provides a detailed account of the ancient Etruscan bronze mirrors in the collections of Cambridge University: those of the Lewis Collection of Corpus Christi College, of the Fitzwilliam Museum itself, and of the Museums of Archaeology and Anthropology and of Classical Archaeology. Copublished with the Fitzwilliam Museum Cambridge

43380-0 Hardback $\$ 95.00$

\section{Corpus of Mycenaean Inscriptions from Knossos}

J. Chadwick, L. Godart, J. T. Killen, J.-P. Olivier, A. Sacconi, and

I. A. Sakellarakis

This is the third volume of the definitive publication, by the world's major Mycenaean epigraphists, of the Linear B tablets found by Sir Arthur Evans at Knossos. It includes all the fragments discarded by Evans and subsequently recovered from the Museum storerooms and elsewhere and represents the results of thirty years' work on reconstituting the documents. Copublished with the Gruppo Editoriale Internazionale

32024-0 Hardback $\$ 250.00$

Now in paperback...
The Archaeology of
Australia's History
Graham Connah
Drawings by Douglas Hobbs
Foreword by John Mulvaney
"... a bighly readable, informative account
which reflects the state of bistoric archaeology
in Australia at present and will be an excellent
benchmark as to its progress in the future."

-Australian Journal

of Historical Archaeology

This book was published originally in hard-

back with the title of the Hut I Builded:

The Archaeology of Australia's History. 45475-1 Paperback $\$ 29.95$

\section{The Prehistoric Exploration and Colonisation of the Pacific \\ Geoffrey Irwin}

"Irwin's study is, quite simply, one of the best books written within the past ten years on the archaeology of the Pacific."

- Choice

Forty years of modern archaeology, experimental voyages in rafts and computer simulations have produced an enormous range of literature on the controversial subject of the exploration and colonization of the Pacific. This book represents a major advance in knowledge of prehistoric settlement.

47651-8 Paperback about $\$ 17.95$

Available in bookstores or from

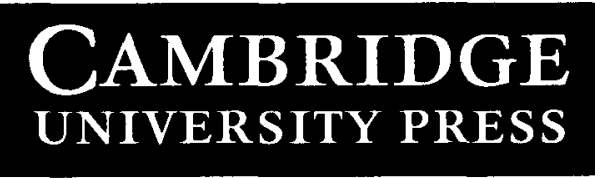

40 West 20th St., N.Y., NY 10011-4211

Call toll-free 800-872-7423

MasterCard/VISA accepted. Prices subject to change. 


\section{NOTICE TO AUTHORS}

American Antiquity publishes original papers on the archacology of the New World, and on archaeological method, theory, and practice worldwide. Authors of papers on Latin American regional topics are encouraged to submit their work to Latin American Antiquity. However, papers on Latin American archacology may be accepted in American Antiquity if they address broad methodological, theoretical, or comparative issues. Authors submit manuscripts to the editor for consideration as ARTICLES, REPORTS, COMMENTS, or FORUM essays. REVIEWS, BOOK NOTES, and OBITUARIES are solicited by the respective associate editors. Information regarding CURRENT RESEARCH should be directed to the managing editor or to the assistant editor for the appropriate region.

Authors should submit an original and four copies of their manuscripts, including all figures, tables, references, and notes. Detailed information on policy, style, and technical matters of manuscript preparation is given in the "Editorial Policy, Information for Authors, and Style Guide for American Antiquity and Latin American Antiquity," which appeared in the October 1992 issue (57[4]:749-770); for additional information, updates, or clarification consult the managing editor.

The editor reserves the right to evaluate manuscripts (with or without peer review) for appropriate subject matter, quality, length, and compliance with the style guide. Manuscripts may be returned to authors if they fail to meet expectations or conform to these guidelines. Manuscripts are evaluated by the editor in consultation with peer refeeres, or by the associate editors, as appropriate. The editor has the final responsibility for all decisions regarding manuscripts. The review process generally takes a minimum of two to four months. Authors will be notified as soon as a decision is reached to accept (outright or with revisions) or reject a manuscript.

To ensure the prompt receipt and handling of manuscripts, please send them to: Dr. Michael W. Graves, Editor, American Antiquity, Department of Anthropology, 2424 Maile Way, Porteus 346. University of Hawaii, Honolulu, HI 96822 . Inquiries regarding the style guide and the production of the journal should be directed to: Janet Walker, Manager, Publications, Society for American Archaeology, 900 Second S1., N.E., Suite 12, Washington, DC 20002; (202) 789-8200. 


\section{CONTENTS}

\section{ARTICLES}

Gradual or Step-Wise Change: The Development of Sedentary Settlement

Patterns in Northeast Mississippi Janet Rafferty

A Formal Approach to the Design and Assembly of Mobile Toolkits Steven L. Kuhn

Wealth Finance in the Inka Empire: Evidence from the Calchaqui Valley,

Argentina

Timothy Earle

\section{OBITUARIES}

William Jean Beeson: 1926-1990

Jay Bouton Crain

Marvin F. Kivett: 1917-1992

David Mayer Gradwohl

\section{REPORTS}

Hedgepeth Mounds, an Archaic Mound Complex in North-Central Louisiana

Joe W. Saunders and Thurman Allen

Accelerator Mass Spectrometry (AMS) Dates Confirm Early Zea mays in the Mississippi River Valley

Thomas J. Riley, Gregory R. Walz, Charles J. Bareis, Andrew C. Fortier, and Kathryn E. Parker

The Effects of Stone and Technology on Fluted-Point Morphometry

Kenneth B. Tankersley

Prehistoric Macaws and Parrots in the Mimbres Area, New Mexico

Darrell Creel and Charmion McKusick

Comparison of $1 / 8$ "- and $1 / 4$ "-Mesh Recovery of Controlled Samples of Smallto-Medium-Sized Mammals

Brian S. Shaffer and Julia L. J. Sanchez

FORUM

Social Archaeology in Latin America: An Appreciation

Thomas C. Patterson

\section{COMMENTS}

Consider the Hermaphroditic Mind: Comment on "The Interplay of Evidential Constraints and Political Interests: Recent Archaeological Research on Gender"

Barbara J. Little

What is Archaeology's "Mitigated Objectivism" Mitigated By? Comments on Wylie

Michael Fotiadis

On "Capturing Facts Alive in the Past" (or Present): Response to Fotiadis and to Little

Alison Wylie

INFORMATION ON CURRENT RESEARCH SUBMISSIONS

Teresita Majewski, Coordinator

REVIEWS AND BOOK NOTES

George T. Jones and Charlotte Beck, Editors 